\title{
抗癌剂投与時における実験的代償性腎肥大の生化学的研究
}

\author{
金沢大学医学部泌尿器科学教室 竹 前 克 朗
(主任: 黒田教授)
}

\section{A BIOCHEMICAL STUDY ON COMPENSATORY RENAL ENLARGEMENT IN UNILATERAL NEPHRECTOMIZED RATS TREATED WITH MITOMYCIN C OR 5-FLUOROURACIL}

\author{
Katsuro Takemae \\ Department of Urology, School of Medicine, Kanazawa University
}

(Director: Prof. K. Kuroda)

Effects of mitomycin $\mathrm{C}$ or 5-fluorouracil on compensatory renal enlargement after unilateral nephrectomy in rats were studied by analyzing patterns of changes in DNA, RNA and protein contents.

The remaining kidneys of rats following unilateral nephrectomy or sham-operated kidneys were removed on the 1st, 3rd, 5 th, 7 th, 10th and 14 th day after the operation. Just after the operation, animals received intraperitoneal injections of either mitomycin C $(0.292 \mathrm{mg} / \mathrm{kg}$ body weight $)$ or 5 -fluorouracil $(21 \mathrm{mg} / \mathrm{kg}$ body weight). DNA, RNA and protein in cortical, medullary and tubular fractions of the removed kidney were determined according to Burton's method, orcinol method and Lowery's method, respectively. The data were expressed as ratios of the values in the left kidney to those of the right kidney in each animal.

In the animals treated with mitomycin $\mathrm{C}$ or 5 -fluorouracil, the increase in kidney weight after unilateral nephrectomy was similar to that of the untreated animals up to the 10th day, but significantly lower on the 14th day. The ratio of cortical weight to medullary weight, however, remained almost constant during the experimental period.

In the nephrectomized control rat, hyperplastic and hypertrophic responses were noticed in both cortex and medulla, as judged from patterns of increments in DNA, RNA and protein contents. However, hyperplastic response which was active between the 1st and 3rd day was somewhat stronger in the cortex than in the medulla. The effect of mitomycin $\mathrm{C}$ to the nephrectomized animals was characterized by severe suppression of hyperplasia in both cortex and medulla, and by remarkable decrease in DNA content on the 7th day, suggesting the presence of destructed nuclei. This decreased level of DNA content recovered rapidly after the 7 th day. The hypertrophic response was not significantly impaired by mitomycin C. A single administration of 5-fluorouracil resulted in a remarkable suppression of hypertrophic response on the 1st day, and a slight decrease in hyperplasia on the 3rd day. Thereafter, no significant change was observed.

On the basis of the above results, clinical meanings of administration of antitumor drugs after nephrectomy were discussed.

要旨：ウィスター系雄性ラットを用いて，代償性腎肥大に抢よぼす mitomycin C あるいは5-fluorouracil の影 響を核酸量および蛋白量の変化を指標として検討した。観察日数は手術後 $1 ， 3 ， 5 ， 7 ， 10 ， 14$ 日目とし， 抗癌剤は $\mathrm{LD}_{50}$ の $1 / 10$ 量を 1 回腹腔内投与した。腎, 皮質, 髄質の各重量ともに, 腎摘除術のみの群では14日 目まで経日的な増加傾向が認められた。一方，抗癌剤投与群では10日目までほぼ同様の傾向が認められたが， 14日後には腎摘除術のみの群に比し有意に低值を示した。細胞の hypertrophy は皮質，䯣質ともに腎摘除術の みの群では 1 月以内に始まり，14日目まで継続していると考兄らたた。一方，hyperplasia は皮質では 1 日目 
と 3 日目の間に強く，以後も軽度でなあるが持続した。㖪質でも同様の傾向であつたが皮質に比し軽度であ つた。これに対し mitomycin C 投与では, 皮質, 髄質の hypertrophy に与える影響は少ないが, hyperplasia に対する抑制は強く，7 日目には細胞の核の崩塤によると考兄られる DNA 含量の著しい低下が浔められ た。しかしその後は急速な回復傾向が認められた。 5-fluorouracil 投与では, 皮質, 䯣質ともに1 日目までの hypertrophy の強い抑制と 3 月目までの hyperplasia の軽度の抑制が認められたが，以後の影響は少なかつた。

\section{緒 言}

泌尿器科領域では種々の腎疾患のために一側腎を摘除 する手術はしばしば経験され，摘除腎が悪性腫瘍の場合 にはしばしば抗癌剤投与が行われている.腎摘除術後の 抗癌剂投与は，その種類によつては腎機能障害を来たす 危険性が大きく，著者は腎癌のため腎摘除術を施行した 患者に mitomycin C を投与し，急性腎不全を来たした 例を経験している。

従来より感染症治療を目的とした抗生剤の腎毒性につ いては数多く報告されているが，抗癌剤については未知 の部分が多い，一方, 片腎摘除後, 対側の残腎に代償性 肥大の生ずることはよく知られた事実であるが1)，腎肥 大に拉よぼす抗癌剤の影響に関する研究も注と儿ど行わ れていないのが現状である，そのため代償性腎肥大に打 よぼす抗癌剤の影響を研究する目的で，ラットを用いて mitomycin C (以下 MMC と略す) あるいは5-fluorouracil (以下 5-Fu と略す) を投与し，腎の皮質，髄質打 よび分離した尿細管の DNA，RNA 㸝よび蛋白含量を測 定し，種々の検討を行つた。

\section{実験方法}

\section{1. 実験動物}

実験動物は12〜16週㱓のウィスター系雄性ラット（平 均体重約 $300 \mathrm{~g}$ ）を使用した。食慨は動物飼育用ペレット （オリェンタル酵母工業）を与兄，飲水は自由とした。

\section{2. 使用抗癌剤}

使用薬剤は MMC 拉よび 5-Fu（協和醗酵株式会社） の 2 凰で, MMC 抢よび 5-Fu は滅菌生理食塩水でそれ ぞれの濃度を $0.1 \mathrm{mg} / \mathrm{ml}$ および $5 \mathrm{mg} / \mathrm{ml}$ に調整した後, $\mathrm{MMC}$ は $0.292 \mathrm{mg} / \mathrm{kg}, 5-\mathrm{Fu}$ は $21 \mathrm{mg} / \mathrm{kg}$ を腹腔内に1回 投与した。

3. 手術方法㧍よび実験群

ペントバルビタール麻醉下にポビドンョードで皮膚消 毒を行つた後, 右背面斜切開にて後腹膜法により右腎を 摘除した群 (N群), 更にその直後に MMC を投与した 群 (NM 群), 同様に 5-Fu を投与した群 (NF 群)をと れぞれ30匹ずつ作成した。また右腎周用を剝離する操作 (偽手術) のみにとどめた群（ $\mathrm{S}$ 群), 更にその直後に
MMC を投与した群 (SM 群)，同様に 5-Fu を投与し た群 (SF 群)をそれぞれ18匹ずつ作成した。手術後 1，3，5，7，10，14日目に N，NM，NF 群はそれぞ れ 5 匹ずつ残存左腎を，S, SM, SF 群はそれぞれ 3 匹ず つ両腎を摘除した. 手術時刻は午後 $2 \sim 4$ 時に定めた.

\section{4. 皮質と䯣質の分離}

摘除腎は周囲の脂肪組織を除去し，重量を測定した 後， $4{ }^{\circ} \mathrm{C}$ のコールドルーム内で皮質と髄質を分離した. すなわちまず腎を前後で切半した後，長軸に垂直に厚さ 1〜2mm にスライスし，ピソセットで皮質と髄質を分 離した.そしてそれぞれを細切した後に重量を測定し， その一部は50倍量の生理食塩水を加えてホモジナイズし た。また抗癌剂非投与群の $\mathrm{N}, \mathrm{S}$ 群㐨よび $\mathrm{MMC}$ 投与群 の NM, SM 群では皮質の一部より尿細管を分離し, 上 記ホモジネートとともに化学的湘定に供した.

\section{5. 尿細管分離}

尿細管の分離は Helwig $ら^{2)}$, Ahn $ら^{3)}$ の方法に準じ た岡所 ${ }^{11}$ の方法に従つて行つた。概略を記述すると， 細 切した皮質の一部を $\mathrm{pH} 7.4$ 亿調整した Hanks 液に入 れ，これに0.1\% collagenase (Type I, Sigma 社製) を加えて $37^{\circ} \mathrm{C} の$ 恒温槽内で振燙し，皮質細胞を分離し た。得られた皮質細胞は Hanks 液に浮遊させて sucrose gradient $(75 \% \mathrm{w} / \mathrm{v} 5 \mathrm{ml}, 57 \% \mathrm{w} / \mathrm{v} 15 \mathrm{ml}, 8.6 \% \mathrm{w} / \mathrm{v} 10$ $\mathrm{ml}$ ）に重層し，1,000gで60分間遠心した後，57\%と8.6 \%の間に分離された層をとり出し，化学的測定に供し た。

\section{6. 化学的測定}

得られた試料に $10 \%$ perchloric acid (PCA) を加えて 10 分間水冷し， $9,000 \mathrm{~g}$ で10分間遠心した．沈渣につい て再び同様の操作を行つた，次にその沈椬に $5 \%$ PCA を加兄て, $90^{\circ} \mathrm{C}$ 恒温槽内で15分間インキュベートし, $25,000 \mathrm{~g}$ で30分間遠心した。沈椬には $1 \mathrm{~N}-\mathrm{NaOH}$ 溶液を 加えて, $60^{\circ} \mathrm{C}$ 恒温槽内で10分間加温溶解したう方, 蛋 白含量を測定した。 DNA 含量は Burton の方法), RNA 含量は orcinol 法5), 蛋白含量は Lowry らの方法 ${ }^{6}$ に従 つて測定した。

ラットの腎重量, DNA, RNA, 蛋白各含量などは個体 
Table 1 Kidney weight (mg) per body weight (g)

\begin{tabular}{c|c|c|c|c|c|c|c}
\hline \multicolumn{2}{c|}{ Days after operation } & 1 & 3 & 5 & 7 & 10 & 14 \\
\hline \multirow{3}{*}{ No drug } & $\mathrm{N}$ & $3.95 \pm 0.11$ & $4.35 \pm 0.28$ & $4.20 \pm 0.31$ & $4.40 \pm 0.27$ & $4.32 \pm 0.07$ & $4.50 \pm 0.21$ \\
\cline { 2 - 8 } & $\mathrm{S}$ & $3.99 \pm 0.55$ & $4.05 \pm 0.37$ & $3.82 \pm 0.21$ & $3.86 \pm 0.19$ & $3.50 \pm 0.04$ & $3.39 \pm 0.09$ \\
\hline \multirow{3}{*}{$\mathrm{MMC}$} & $\mathrm{NM}$ & $4.03 \pm 0.15$ & $4.03 \pm 0.18$ & $4.40 \pm 0.28$ & $4.32 \pm 0.35$ & $4.39 \pm 0.12$ & $4.22 \pm 0.15$ \\
\cline { 2 - 8 } & $\mathrm{SM}$ & $3.18 \pm 0.27$ & $3.65 \pm 0.27$ & $3.76 \pm 0.27$ & $3.27 \pm 0.11$ & $3.71 \pm 0.08$ & $3.57 \pm 0.34$ \\
\hline \multirow{3}{*}{$5 \cdot \mathrm{Fu}$} & $\mathrm{NF}$ & $4.89 \pm 0.30$ & $3.66 \pm 0.16$ & $4.94 \pm 0.07$ & $3.74 \pm 0.16$ & $4.54 \pm 0.12$ & $4.35 \pm 0.09$ \\
\cline { 2 - 8 } & $\mathrm{SF}$ & $4.18 \pm 0.14$ & $4.15 \pm 0.04$ & $4.07 \pm 0.17$ & $3.83 \pm 0.13$ & $3.50 \pm 0.09$ & $4.02 \pm 0.21$ \\
\hline
\end{tabular}

Mean \pm S. E.

$\mathrm{N}$ : nephrectomy ( 5 rats), S : sham ( 3 rats), NM : nephrectomy

+ MMC (5 rats), SM : sham + MMC (3 rats), NF: nephrectomy

+5 - Fu (5 rats), SF : sham + 5-Fu (3 rats)

Table 2 Effects of MMC or 5-Fu on kidney weight and rats.

\begin{tabular}{|c|c|c|c|c|c|c|c|c|}
\hline \multicolumn{3}{|c|}{ Days after operation } & 1 & 3 & 5 & 7 & 10 & 14 \\
\hline \multirow{6}{*}{$\begin{array}{l}\text { Kidney } \\
\text { weight } \\
\text { (mg) }\end{array}$} & \multirow{2}{*}{ No drug } & $\mathrm{R}$ & $940 \pm 81$ & $1477 \pm 50$ & $1158 \pm 56$ & $954 \pm 22$ & $774 \pm 34$ & $889 \pm 24$ \\
\hline & & $\mathrm{L}$ & $971 \pm 91$ & $1472 \pm 71$ & $1126 \pm 68$ & $956 \pm 26$ & $819 \pm 19$ & $895 \pm 26$ \\
\hline & \multirow{2}{*}{$\mathrm{MMC}$} & $\mathrm{R}$ & $1169 \pm 153$ & $1171 \pm 73$ & $1170 \pm 105$ & $923 \pm 64$ & $821 \pm 41$ & $1150 \pm 55$ \\
\hline & & $\mathrm{L}$ & $1099 \pm 143$ & $1108 \pm 55$ & $1182 \pm 94$ & $964 \pm 13$ & $861 \pm 41$ & $1183 \pm 36$ \\
\hline & \multirow{2}{*}{$5-\mathrm{Fu}$} & $\mathrm{R}$ & $934 \pm 31$ & $1110 \pm 65$ & $935 \pm 18$ & $954 \pm 22$ & $831 \pm 26$ & $1220 \pm 10$ \\
\hline & & $\mathrm{L}$ & $934 \pm 29$ & $1032 \pm 21$ & $950 \pm 20$ & $957 \pm 25$ & $850 \pm 38$ & $1262 \pm 57$ \\
\hline \multirow{6}{*}{$\begin{array}{l}\text { DNA } \\
\text { concentration } \\
\text { (mg/g tissue) }\end{array}$} & \multirow{2}{*}{ No drug } & $\mathrm{R}$ & $4.23 \pm 0.43$ & $2.87 \pm 0.46$ & $2.67 \pm 0.41$ & $4.67 \pm 0.50$ & $3.40 \pm 0.11$ & $3.02 \pm 0.11$ \\
\hline & & $\mathrm{L}$ & $4.06 \pm 0.50$ & $2.57 \pm 0.32$ & $2.72 \pm 0.46$ & $4.75 \pm 0.90$ & $3.20 \pm 0.21$ & $2.91 \pm 0.20$ \\
\hline & \multirow{2}{*}{ MMC } & $\mathrm{R}$ & $3.22 \pm 0.44$ & $3.57 \pm 0.31$ & $2.05 \pm 0.17$ & $3.57 \pm 0.44$ & $3.70 \pm 0.20$ & $2.42 \pm 0.09$ \\
\hline & & $\mathrm{L}$ & $3.31 \pm 0.46$ & $3.84 \pm 0.28$ & $1.95 \pm 0.11$ & $3.62 \pm 0.48$ & $3.35 \pm 0.10$ & $2.46 \pm 0.16$ \\
\hline & \multirow{2}{*}{$5-\mathrm{Fu}$} & $\mathrm{R}$ & $3.41 \pm 0.24$ & $3.30 \pm 0.06$ & $3.13 \pm 0.06$ & $3.65 \pm 0.34$ & $3.51 \pm 0.07$ & $3.90 \pm 0.15$ \\
\hline & & L & $3.56 \pm 0.34$ & $3.47 \pm 0.11$ & $3.04 \pm 0.20$ & $3.62 \pm 0.17$ & $3.60 \pm 0.18$ & $3.72 \pm 0.19$ \\
\hline \multirow{6}{*}{$\begin{array}{l}\text { RNA } \\
\text { concentration } \\
\text { (mg/g tissue })\end{array}$} & \multirow{2}{*}{ No drug } & $\mathrm{R}$ & $5.95 \pm 0.97$ & $3.84 \pm 0.29$ & $4.13 \pm 0.89$ & $5.57 \pm 0.24$ & $5.21 \pm 0.17$ & $5.61 \pm 0.11$ \\
\hline & & L & $5.72 \pm 0.75$ & $3.52 \pm 0.45$ & $4.21 \pm 0.92$ & $5.54 \pm 0.45$ & $5.05 \pm 0.10$ & $5.54 \pm 0.16$ \\
\hline & \multirow{2}{*}{$\mathrm{MMC}$} & $\mathrm{R}$ & $5.06 \pm 0.23$ & $4.72 \pm 0.06$ & $4.81 \pm 0.12$ & $4.91 \pm 0.42$ & $5.93 \pm 0.24$ & $5.29 \pm 0.18$ \\
\hline & & L & $5.31 \pm 0.06$ & $4.83 \pm 0.22$ & $4.93 \pm 0.25$ & $4.97 \pm 0.29$ & $5.87 \pm 0.14$ & $5.19 \pm 0.07$ \\
\hline & \multirow{2}{*}{$5 \cdot F u$} & $\mathrm{R}$ & $4.92 \pm 0.23$ & $4.85 \pm 0.23$ & $4.95 \pm 0.16$ & $5.32 \pm 0.08$ & $5.24 \pm 0.09$ & $4.89 \pm 0.23$ \\
\hline & & L & $5.22 \pm 0.11$ & $5.09 \pm 0.15$ & $4.86 \pm 0.14$ & $5.34 \pm 0.17$ & $5.27 \pm 0.07$ & $4.97 \pm 0.31$ \\
\hline \multirow{6}{*}{$\begin{array}{l}\text { Protein } \\
\text { concentration } \\
(\mathrm{mg} / \mathrm{g} \text { tissue })\end{array}$} & \multirow{2}{*}{ No drug } & $\mathrm{R}$ & $161 \pm 9$ & $113 \pm 6$ & $99.3 \pm 10.8$ & $166 \pm 4$ & $102 \pm 5$ & $100 \pm 4$ \\
\hline & & L & $154 \pm 7$ & $113 \pm 1$ & $104 \pm 9$ & $171 \pm 5$ & $117 \pm 3$ & $98.6 \pm 3.4$ \\
\hline & \multirow{2}{*}{$\mathrm{MMC}$} & $\mathrm{R}$ & $89.5 \pm 1.0$ & $112 \pm 3$ & $92.3 \pm 5.1$ & $106 \pm 6$ & $113 \pm 5$ & $92.5 \pm 2.6$ \\
\hline & & L & $94.2 \pm 4.0$ & $110 \pm 2$ & $92.1 \pm 2.1$ & $110 \pm 2$ & $122 \pm 5$ & $96.9 \pm 5.1$ \\
\hline & \multirow{2}{*}{$5-\mathrm{Fu}$} & $\mathrm{R}$ & $98.5 \pm 2.4$ & $101 \pm 4$ & $90.6 \pm 3.9$ & $100 \pm 6$ & $98.9 \pm 2.1$ & $114 \pm 8$ \\
\hline & & $\mathrm{L}$ & $107 \pm 5$ & $114 \pm 8$ & $93.3 \pm 4.3$ & $103 \pm 5$ & $106 \pm 1$ & $111 \pm 1$ \\
\hline
\end{tabular}

Mean \pm S. E. , R : Right, L : Left 
差が大きく, 統計処理を行つても実験成績の検討は困難 であつた。しかし同一個体に抢ける左右腎の值の比はほ ぼ一定であるので，原則として右腎の值に対する左腎の 值の比（左腎值/右腎值, 以下左右比と略す) で比較検 討した。

\section{実験成績}

1. 体重就よび体重に対する左腎重量の比

ラットの実験開始時の体重は平均で $300 \mathrm{~g}$ 前後であつ た.体重の変化を実験開始時に対する終了時の比で検討 すると，いずれの群でも10日目まで約1.0であり，14日 目に N, SM, SF 群ではそれぞれ1.23，1.17，1.28のご とく増加したが，NM, NF, S 群では約1.0で変化は愢め られなかつた。

体重に対する左腎重量の比（左腎重量 $\mathrm{mg} /$ 体重 $\mathrm{g}$ ）を
みると，N，NM，NF の 3 群ではいずれも為手術をほど こした S, SM, SF 群に比し高值の傾向であつたが, 個 体差が大きく有意の变化とはい光ず，また $\mathrm{N}, \mathrm{NM}, \mathrm{NF}$ の 3 群の間にも有意の変化は認められなからた（Table 1).

2. 偽手術群の腎に打よぼす MMC 抢よび 5-Fuの影 響

偽手術を浪どこした S，SM，SF の3群について，腎 重量掞よび DNA，RNA, 蛋白各含量の推移を Table 2 に 示した。これらの值はいずれも個体差が大きく， MMC 抢よび 5-Fu 投与群と非投与群との間に有意の変化は認 められないため, MMC 抢よび 5-Fu は偽手術群の腎重 量抢よび DNA, RNA，蛋白各含量におよぼす影響は少な いと考えられた. Table 2 で明らかなように，各測定傎

Table 3 Individual differences and extents of distribution in kidney weights or macromolecular contents.

\begin{tabular}{l|c|c|c|c}
\hline & $\begin{array}{c}\text { Range } \\
(\text { Max. } \\
\text { Min. }\end{array}$ & Mean & $\begin{array}{c}\text { Maximal difference } \\
\text { from mean per mean } \\
(\%)\end{array}$ & $\begin{array}{c}\text { Coefficient * } \\
\text { of variation } \\
(\%)\end{array}$ \\
\hline Kidney weight & $1609 \sim 733$ & 1034 & 55.6 & 18.1 \\
\hline DNA concentration & $5.90 \sim 1.82$ & 3.34 & 76.6 & 23.3 \\
\hline RNA concentration & $7.82 \sim 2.38$ & 5.07 & 54.2 & 14.5 \\
\hline Protein concentration & $180 \sim 82$ & 110 & 63.6 & 19.4 \\
\hline $\begin{array}{l}\text { Ratio (left/right) } \\
\text { in kidney weight }\end{array}$ & $1.11 \sim 0.84$ & 1.00 & 16.0 & 5.4 \\
\hline $\begin{array}{l}\text { Ratio (left/right) } \\
\text { in DNA concentration }\end{array}$ & $1.18 \sim 0.78$ & 0.99 & 22.2 & 10.0 \\
\hline $\begin{array}{l}\text { Ratio (left/right) } \\
\text { in RNA concentration }\end{array}$ & $1.16 \sim 0.75$ & 1.00 & 25.0 & 7.3 \\
\hline $\begin{array}{l}\text { Ratio (left/right) } \\
\text { in protein concentration }\end{array}$ & $1.29 \sim 0.87$ & 1.04 & 24.0 & 9.1 \\
\hline
\end{tabular}

* Standard deviation

Mean

Table 4 Cortex weight (mg) per medulla weight (mg)

\begin{tabular}{l|c|c|c|c|c|c|c}
\hline \multicolumn{2}{c|}{ Days after operation } & 1 & 3 & 5 & 7 & 10 & 14 \\
\hline \multirow{3}{*}{ No drug } & $\mathrm{N}$ & $9.20 \pm 0.55$ & $9.45 \pm 0.30$ & $8.95 \pm 0.80$ & $8.60 \pm 0.50$ & $9.50 \pm 0.65$ & $9.70 \pm 1.02$ \\
\cline { 2 - 8 } & $\mathrm{S}$ & $9.33 \pm 0.90$ & $9.55 \pm 1.12$ & $8.85 \pm 1.20$ & $9.58 \pm 0.37$ & $9.65 \pm 0.66$ & $9.43 \pm 0.20$ \\
\hline \multirow{3}{*}{$\mathrm{MMC}$} & $\mathrm{NM}$ & $10.1 \pm 0.9$ & $8.01 \pm 1.15$ & $9.52 \pm 0.36$ & $9.76 \pm 1.03$ & $9.20 \pm 0.62$ & $9.92 \pm 0.69$ \\
\cline { 2 - 8 } & $\mathrm{SM}$ & $8.65 \pm 0.82$ & $8.40 \pm 1.12$ & $9.99 \pm 0.33$ & $9.57 \pm 1.50$ & $9.57 \pm 0.45$ & $9.57 \pm 0.82$ \\
\hline \multirow{3}{*}{$5-\mathrm{Fu}$} & $\mathrm{NF}$ & $9.49 \pm 0.31$ & $8.29 \pm 0.17$ & $9.49 \pm 0.57$ & $10.1 \pm 0.6$ & $9.15 \pm 0.80$ & $9.91 \pm 0.62$ \\
\cline { 2 - 8 } & $\mathrm{SF}$ & $9.67 \pm 1.90$ & $9.90 \pm 1.42$ & $10.2 \pm 1.2$ & $8.17 \pm 0.37$ & $8.40 \pm 0.56$ & $9.82 \pm 0.97$ \\
\hline
\end{tabular}

Mean \pm S. E.

$\mathrm{N}$ : nephrectomy ( 5 rats), S: sham ( 3 rats), NM : nephrectomy

+ MMC (5rats), SM : sham + MMC (3 rats), NF : nephrectomy

$+5-\mathrm{Fu}$ (5 rats), SF : sham + 5-Fu (3 rats) 
に打ける個体差は大きいが，それを左右比でみるときわ めて近接している. Table 3 飞各測定值に扣ける個体差 扣よび左右比でみた際の差の程度を示した。各測定値と もに個体差は大きく，平均值より各測定値の最大のへ だたりを平均值で除した值 (maximal difference from mean per mean) の百分率は最大 $76.6 \%$ に達し, 変動係 数 (coefficient of variation) の百分率は $14.5 \sim 23.0 \%$ となる。これに対し左右比では前者は最大でも25.0\%， 後者は $10.0 \%$ 以下にすぎない.すなわち腎に括ける各測 定值は個体間では著しい差が認められるが，同一個体内 の左右腎ではほぼ同一と考㝋られる，以後の代償性肥大 腎の実験に执いては，上記の理由で左右比で比較検討し た。

3. 代償性肥大腎に拈よぼす MMC，括よび 5-Fuの影 響

1）腎，皮質㧍よび髄質重量（Fig. 1，Table 4)

腎重量を左右比でみると，N群では経日的に增加し， 14日目には実験開始時に 比し約 $40 \%$ 増加が認められ た. 抗癌剤投与.群の NM，NF 群では10日目むでN群と ほ注同様の増加傾向を示したが，14日目にはそれぞれ $1.13 \pm 0.04$ (mean土S.E. 以下同じ), $1.21 \pm 0.03 て ゙, N$ 群に比し有意の低值を示した.

皮質特よび髄質重量を左右比でみると，阿者とも $\mathrm{N}$, $\mathrm{NM}, \mathrm{NF}$ の 3 群ではいずれる腎重量の変化に類似した 推移を示した。すなわちN群では皮質および䯣質重量と も経日的に増加し，14日目に皮質重量は約37\%，䯣質重 量は約 $46 \%$ の増加が認められた。抗癌剂投与群の NM, NF 群では皮質, 髄質重量とも10日目まで増加傾向が認 められたが，14日目にN群に比し低值を示した。

左腎の髄質に対する皮質の重量比（皮質重量 $\mathrm{mg} /$ 髄質 重量 $\mathrm{mg}$ ）をみると， N, NM，NF 群拈よび為手術をほ どこした $\mathrm{S}, \mathrm{SM}, \mathrm{SF}$ 群ともに 9.0 前後であつた。

2) DNA 含量 (Fig. 2)

皮質 DNA 濃度 (mg/g tissue) を左右比でみると, N 群では 1 日目に軽度に減少し，3 日目にやや回復傾向は みられたが，14日目まで漸減傾向が認められた。抗癌剂 投与群の NM 群では 3 日目より減少に転じ， 7 日目に $0.69 \pm 0.08$ と最低值を示した後，14日目まで急速な回復 傾向が認められた。また NF 群では 3 日目より減少に 転じ，以後10日目末でほぼ横ばいで推移したが，14日目

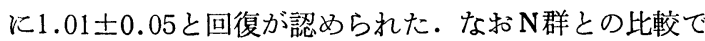
みた場合, NM 群では 7, 10 日目に有意の低值を示し た $(\mathrm{p}<0.05, \mathrm{t}$ 検定による). 皮質の総 DNA 量（皮質
Fig. 1 Effects of MMC and 5-Fu on total, cortical and medullary weight of remaining kidney after nephrectomy. Vertical bars represent standard errors. O-O : nephrectomy (N), - - : nephrectomy+MMC (NM), $\square-\square:$ nephrectomy +5 $\mathrm{Fu}(\mathrm{NF})$
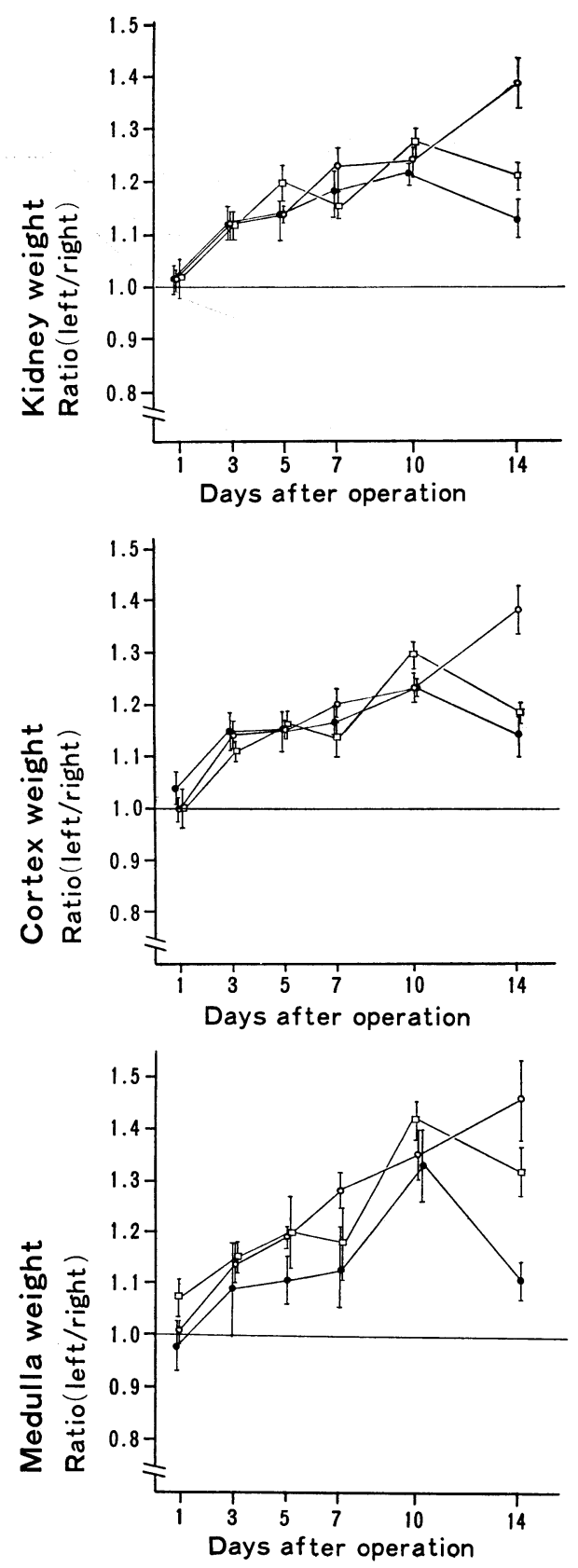
Fig. 2 Effects of MMC and 5-Fu on DNA contents in cortex and medulla of compensatory enlarging kidney. Vertical bars represent standard errors. $\mathrm{O}-\mathrm{O}:$ nephrectomy $(\mathrm{N}),-\bullet:$ nephrectomy + MMC (NM), $\square-\square:$ nephrectomy +5-Fu (NF)

Cortex : DNA concentration

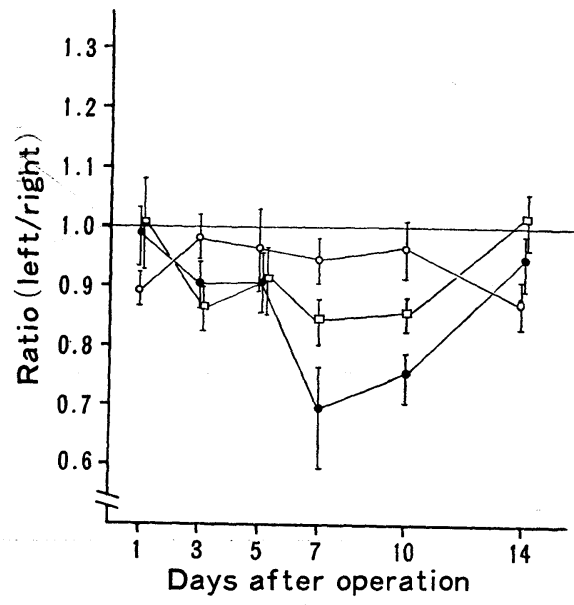

Medulla : DNA concentration

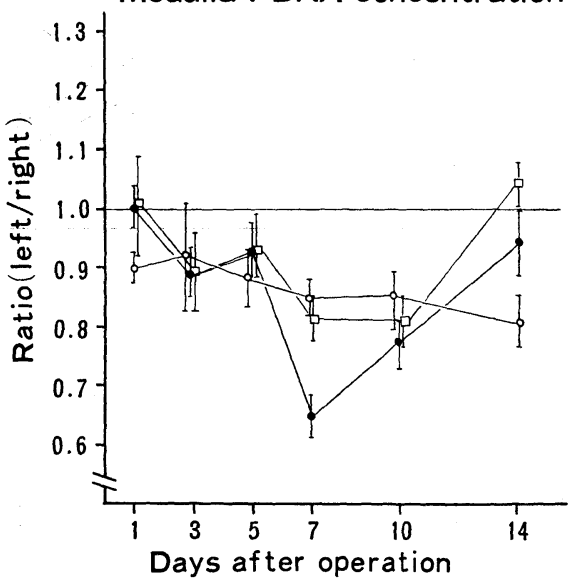

DNA 濃度×皮質重量)を左右比でみると，N群では3 日目までに約10\%増加し, 以後14日目の1.21士0.07まで ゆるやかな増加傾向が涩められた。抗癌剤投与群の NM 群では 5 日目までわずかな増加で推移し，7日目に0.81 士0.06と高度の減少を示した後，14日目まで急速な回復 傾向が認められた。また NF 群では 5 日目までわずかな 増加で推移し，7日目以降は軽度の増加傾向が認められ た。

これに対して髄質に和けるDNA 濃度は，N群では皮 質の変化にほ医類似していたが，3日目以降の值は皮質
Cortex : total DNA

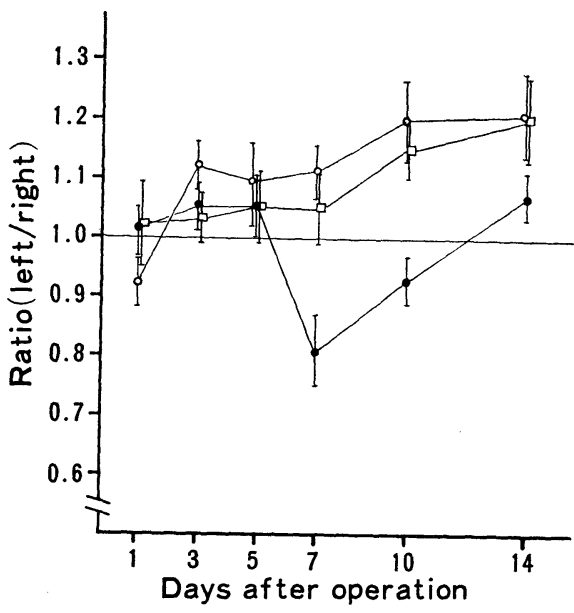

Medulla : total DNA

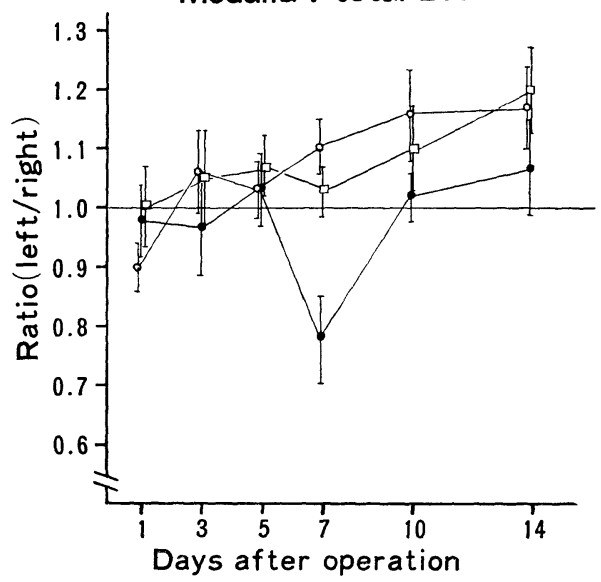

に比し低值であつた。抗嵒剤投与群の NM, NF 群では いずれも皮質の変化に類似していた.なお $\mathrm{N}$ 群との比較 でみた場合, NM 群では7日目に有意の低値を, NF 群 では14日目に有意の高值を示した $(\mathrm{p}<0.01)$. 総 DNA 量はN群ではゆるやかに増加したが，3 日目以降の值は 皮質に比し低值であつた. 抗癌剂投与群の NM, NF 群 では，いずれも皮質の変化に汪㜔類似していた。な拉 $\mathrm{N}$ 群との比較でみた場合, NM 群では7 日目に有意の低值 を示した $(\mathrm{p}<0.01)$.

3) RNA 含量 (Fig. 3) 
Fig. 3 Effects of MMC and 5-Fu on RNA contents in cortex and medulla of compensatory enlarging kidney. Vertical bars represent standard errors. $\mathrm{O}-\mathrm{O}:$ nephrectomy $(\mathrm{N}), \bullet-\bullet$ : nephrectomy + MMC (NM), $\square-\square:$ nephrectomy +5-Fu (NF)

\section{Cortex : RNA concentration}

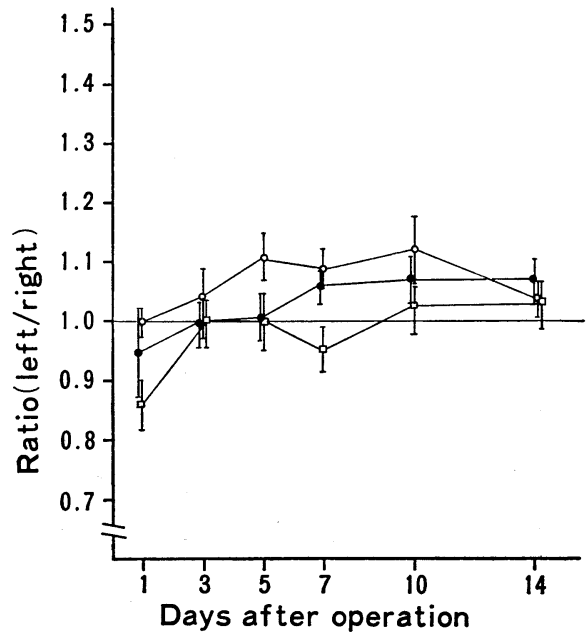

Medulla : RNA concentration

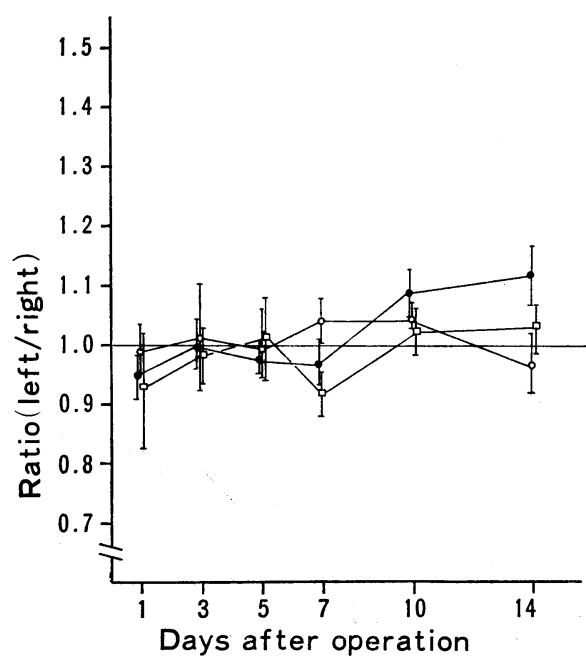

皮質 RNA 濃度 (mg/g tissue) を左右比でみると、N 群では 3 日目より増加傾向が認められ，5 日目より比較 的高值で推移したが，有意の変化とは認められなから た. 抗癌剤投与群の NM 群では, 1 日目にわずかな減 少, 3 日目以降は軽度の増加がみられたが，ほぼ1.0で 推移した。また NF 群では 1 日目に0.86士0.04 と減少を 示したが，3日目以降はほぼ1.0で推移した. な招 $\mathrm{N}$ 群と

\section{Cortex : total RNA}

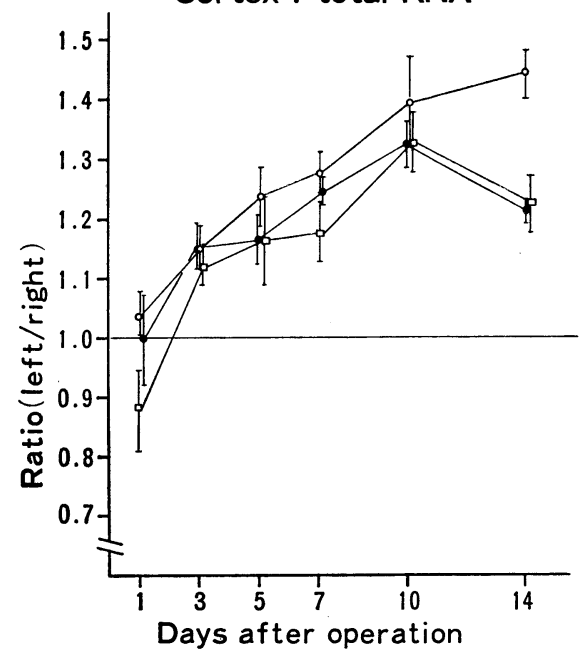

Medulla : total RNA

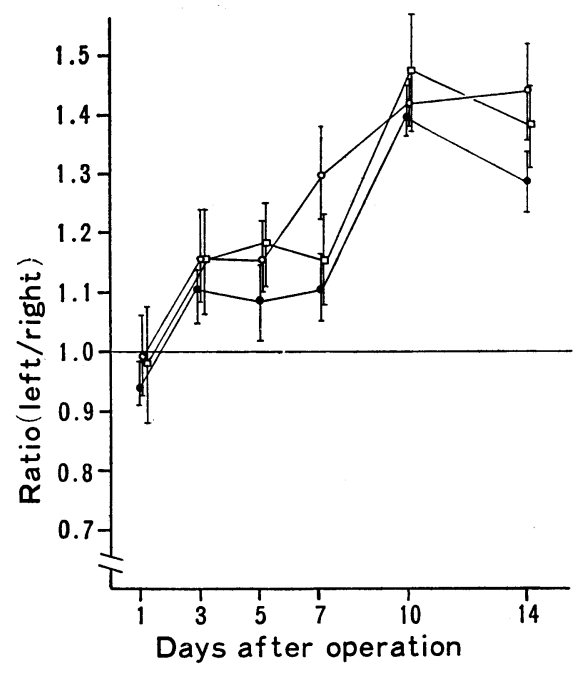

の比較でみた場合, NF 群では 1,7 日目に有意の低值 を示した $(\mathrm{p}<0.05)$. 皮質の総 RNA 量（皮質 RNA 濃 度 $\times$ 皮質重量）を左右比でみると，N群では1 日目より 経日的に増加し，14日目に1.45士0.03と著明な増加が認 められた。抗澏剤投与群の NM, NF 群では 1 日目に増 加は認められず，特に NF 群では軽度の減少が認められ たが，以後両群とも10日目までN群の変化に類似した増 
加傾问が認められた。しかし14日目にN群に比し有意の 低值を示した $(\mathrm{p}<0.01)$.

これに対して髄質に和ける RNA 濃度は, N, NM, NF の3群ではいずれも多少の変動が認められたが，全体と してほぼ1.0で推移した。総 RNA 量はN群では 3 日目 より注添経日的に增加し，14日目に1.44土0.08 と最も顕 著な増加が認められた。抗癌剂投与群の NM, NF 群で は3 日目より増加傾问を示し, 経過中やや増加に鈍化が
みられたが，10日目にそれぞれ1.41士0.04，1.47士0.10 と増加のピークを示し，14日目に増加率は低下した。

4）蛋白含量 (Fig. 4)

皮質蛋白濃度 (mg/g tissue) を左右比でみると，N群 では14日目まで注ぼ1.0で推移した。抗癌剤投与群の $\mathrm{NM}$ 群では 7 日目にやや減少し, NF 群では 1 日目に $0.81 \pm 0.08$ と減少が認められたが，両群ともにほぼ1.0 で推移した．皮質の総蛋白量（皮質蛋白濃度 $\times$ 皮質重

Fig. 4 Effects of $\mathrm{MMC}$ and 5-Fu on protein contents in cortex and medulla of compensatory enlarging kidney. Vertical bars represent standard errors. O-O : nephrectomy (N), nephrectomy+MMC (NM), $\square-\square:$ nephrectomy+5-Fu (NF)

Cortex : protein concentration

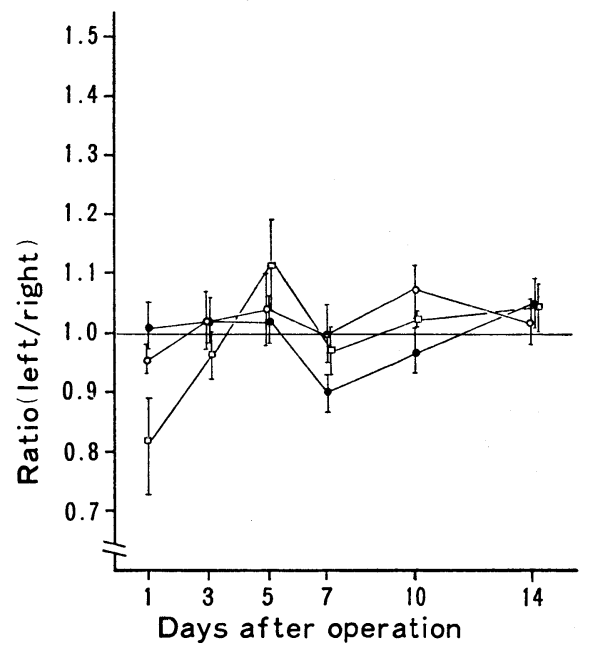

Medulla : protein concentration

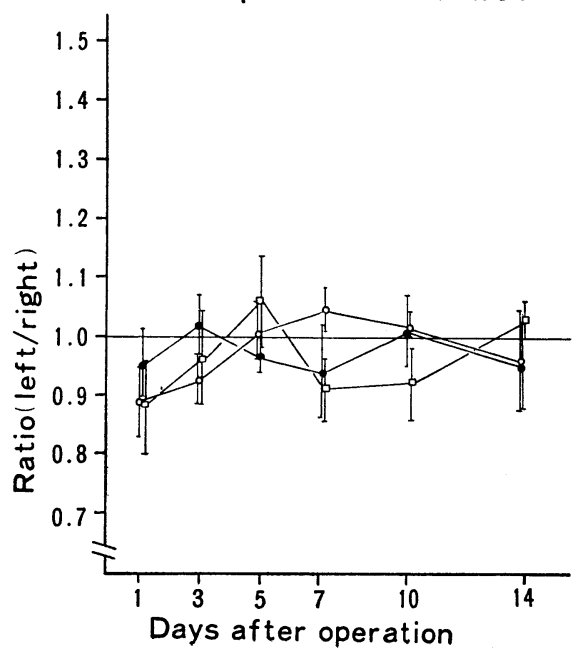

Cortex : total protein

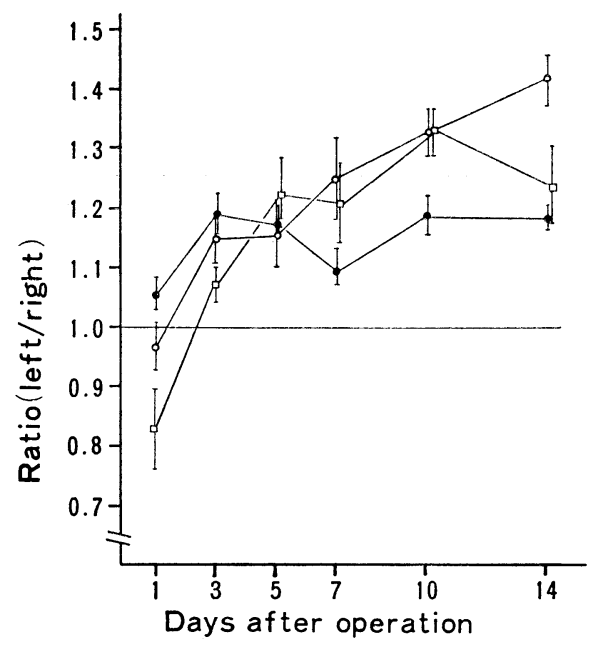

Medulla : total protein

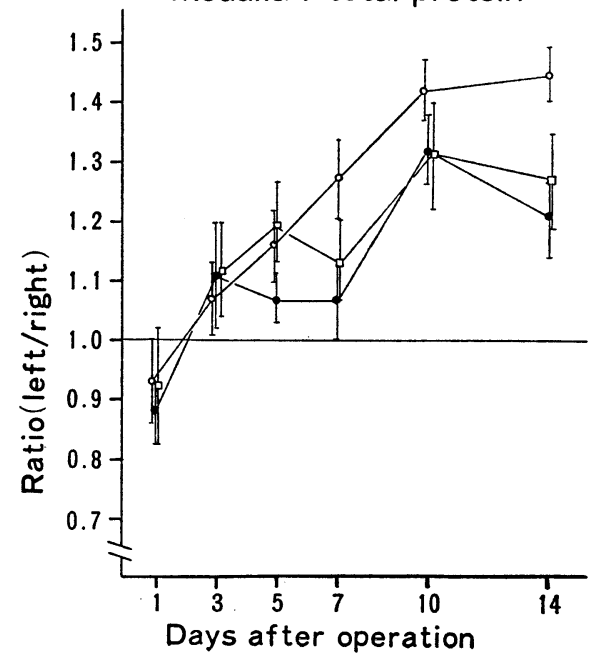


量）を左右比でみると，N群では 3 日目より増加傾向を 示し，14日目に1.42士0.04で増加が最も影著であつた. 抗癌剤投与群の NM 群では1日目より増加傾向が認め られたが，3 日目より横ばい状態で推移した。また NF 群では 1 日目に0.83土0.07と減少し，3 日目より増加に 転じ, 以後10日目までN群の変化に類似した推移を示し
たが，14日目にはN群に比し低值であつた。なお $\mathrm{N}$ 群と の比較でみた場合, NM 群では10，14日目に有意の低值 を示した $(10$ 日目 $\mathrm{p}<0.05 ， 14$ 日目 $\mathrm{p}<0.01)$.

これに対して髄質に打将蛋濃度は，N，NM，NF の3群ではいずれも多少の変動は認められたが，ほぼ 1.0で推移した。総蛋白量はN群では3日目より経日的

Fig. 5 Effects of MMC and 5-Fu on RNA/DNA ratio and protein/DNA ratio in cortex and medulla of compensatory enlarging kidney. Vertical bars represent standard errors. O-O : nephrectomy (N), -๑ : nephrectomy+MMC (NM), $\square-\square:$ nephrectomy+5-Fu (NF)

\section{Cortex : RNA/DNA}

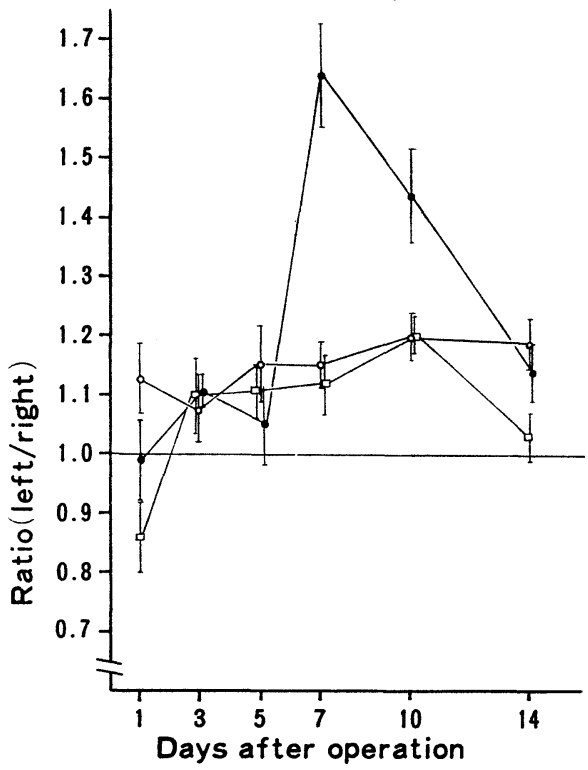

Medulla : DNA/RNA

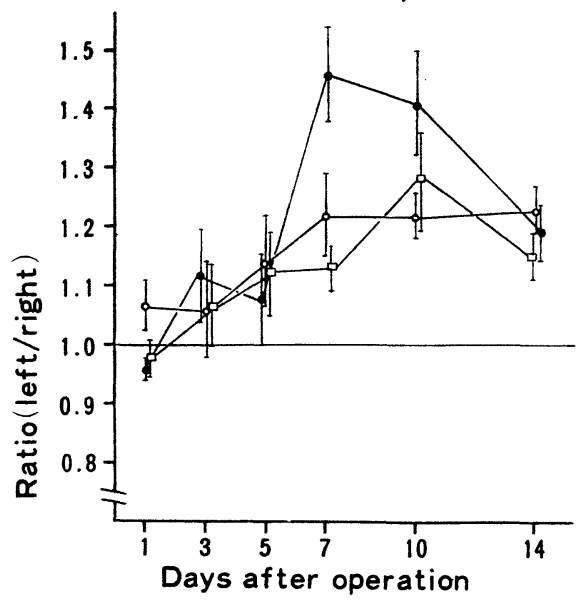

Medulla : protein/DNA

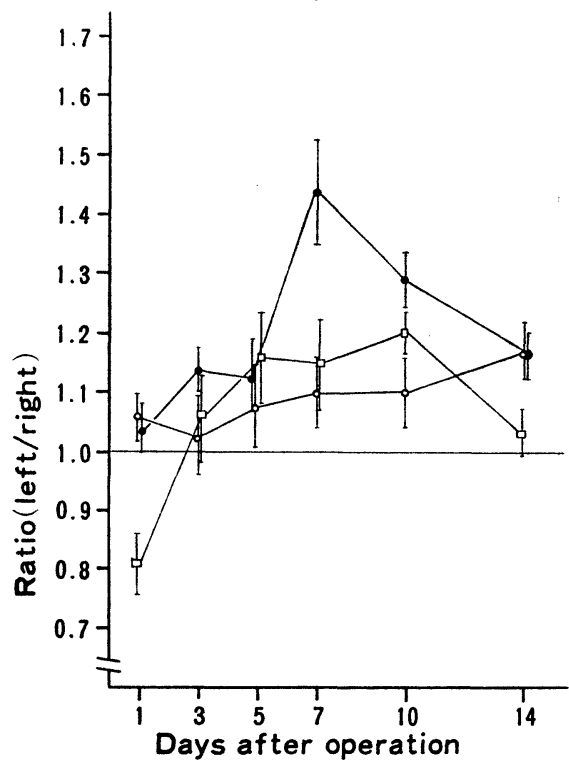

Medulla : protein/DNA

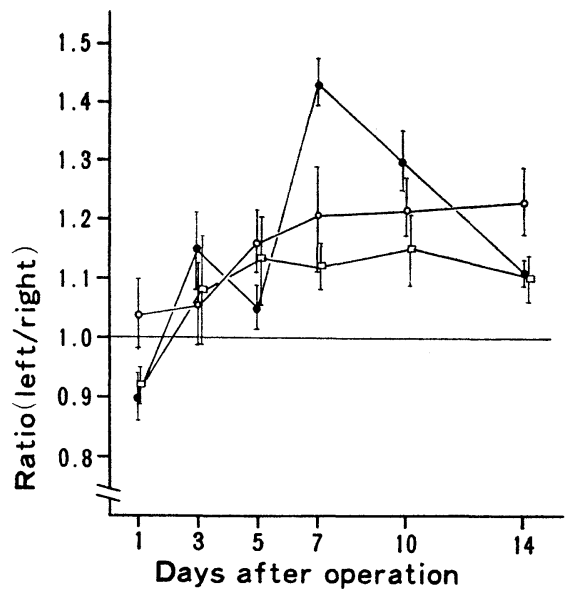


に増加し，14日目に1.45士0.04で増加のピークが認めら れた。抗癌剤投与群の NM，NF 群では 3 日目より増加 傾向を示し，経過中増加にやや釷化がみられたが，10日 目に增加のピークを示し，14日目に增加率は低下した。 なお $\mathrm{N}$ 群との比較でみた場合, NM, NF 群ではいずれる 14日目に有意の低值を示した $(\mathrm{p}<0.05)$.

5） RNA/DNA 比抒よび蛋白/DNA 比 (Fig. 5)

細胞 1 個当りの相対的 RNA 量牰よび蛋白量をみる ために, DNA 量に対する比をとつて検討した。皮質の RNA/DNA 比を左右比でみると，N群では1日目より增 加が認められ，3日目に若干増加率が低下したが，以後 14日目までゆるやかな増加傾向が認めら机た。抗癌剂投 与群の NM 群では 3 日目より増加し，7日目に1.64士 0.09 と著しい増加が認められたが，その後増加率は14日 目まですみやかに低下した。また NF 群では 1 日目に減 少し，3 日目より増加に転じ，10日目までゆるやかな増 加傾向が認められたが，14日目に増加率は低下した。

これに対して䯑質に和けるRNA/DNA 比は，N群では 皮質の変化に類似して招り，1 日目より増加傾向が認め られ，3 日目以降比較的高值で推移した。抗癌剤投与群 の NM 群では 7 日目に1.46士0.08で皮質の值に比し低 值であつたが，全体として皮質の変化に類似していた。
また NF 群では 1 日目にわずかに減少し，以後10日目に 比較的高值を示したが，全体として14日目までゆるやか な増加傾向が認められた。

次に皮質の蛋白/DNA 比を左右比でみると，N群では RNA/DNA 比の変化飞類似した推移を示したが， RNA/ DNA 比の值に比し全体低值であつた。抗癌剤投与群 の NM 群では 3 日目より軽度に增加し，7 日目に 1.44 \pm 0.09 と著しい増加が認められ, 以後增加率は比較的す みやかに低下した。また NF 群では 1 日目に0.81士0.05 と減少したが，3日目より増加に転じ，10日目までゆる やかな増加を示したが，14日目に増加率は低下した。

これに対して䯣質に物ける蛋白/DNA 比は，N群では 1 日目より增加が認められたが軽度であり，3日目以降 は皮質の蛋白/DNA 比に比較し高值で推移した。抗癌剤 投与群の NM, NF 群では 1 日目に減少が認められたが， 3 日目より増加に転じ, 以後両群とも皮質の変化比類似 していた。

6）尿細管 RNA/DNA 比拈よび蛋白/DNA 比 (Fig. $6)$.

尿細管細胞は分離過程 で定量的回収が 困難なことよ り，DNA に対する比で検討した。 RNA/DNA 比を左右 比でみると，N群では1日目よりわずかな増加を示し，

Fig. 6 Effects of MMC and 5-Fu on RNA/DNA ratio and protein/DNA ratio in tubules of compensatory enlarging kidney. Vertical bars represent standard errors. $\mathrm{O}-\mathrm{O}:$ nephrectomy $(\mathrm{N})$, - - : nephrectomy+MMC (NM)

Tubules : RNA/DNA

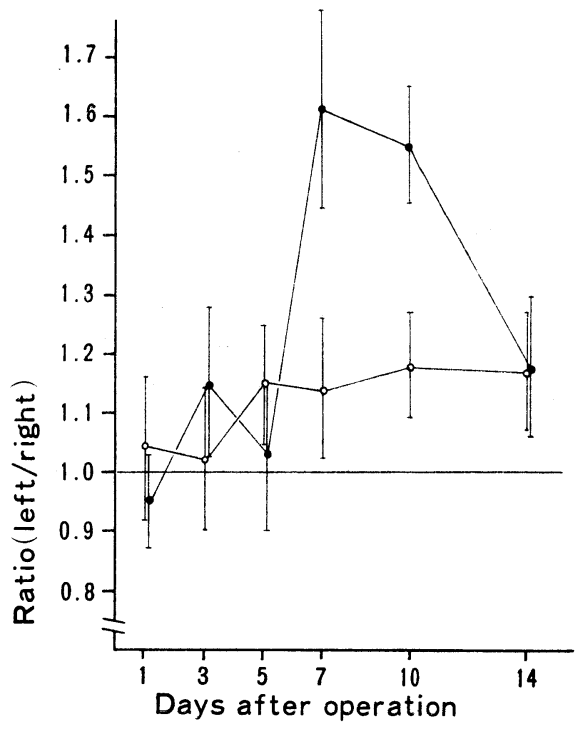

Tubules : protein/DNA

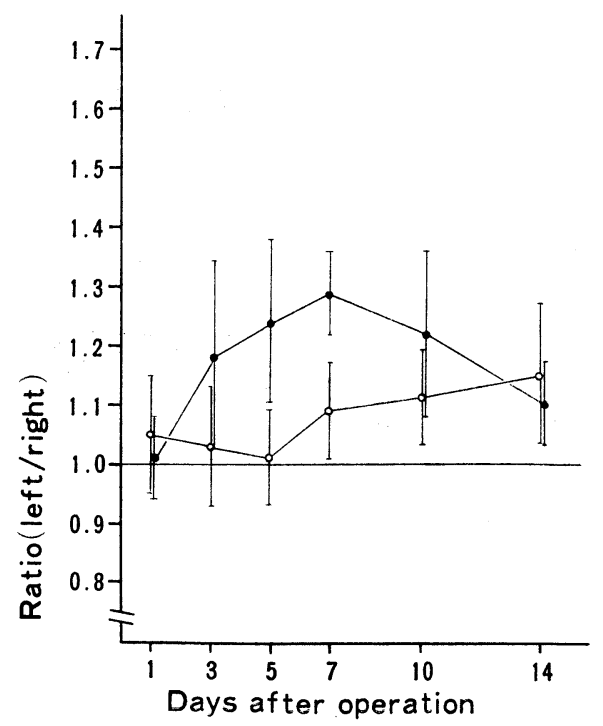


5 日目に1.15士0.10となり，以後ほぼ同值で推移した。 MMC 投与の NM 群では皮質の変化に類似しており, 7 日目に1.61士0.10で増加のピークが認められ, 以後増 加率は低下した。な打 $\mathrm{N}$ 群との比較でみた場合, NM 群 では 7，10日目に有意の高值を示した $(\mathrm{p}<0.05)$. 次に 蛋白/DNA 比を左右比でみると，N群では 5 日目までわ ずかな増加であつたが, 以後軽度の増加傾向が認められ た. NM 群では 1 日目より増加傾向が認められ，7 日目 に1.29土0.07で増加のピークを示し, 以後増加率は低下 した。

\section{考按}

一側腎を摘除すると対側の残腎が肥大する現象は，以 前からよく知られた事実である. 腎は元来細胞回転の活 発でない蔵器 であるといわれている778) が，代償性肥大 の際には細胞の肥大, 増殖とその代謝が立進し, 細胞回 転が活発になることが知られている。一方，今日使用さ れている抗癌阂はそのほとんどが核酸合成阻害作用を有 しているために, 副作用も細胞回転の活発な臓器に生じ やすいことはいうまでもない。そのため腎摘除術後に抗 癌剤を投与した際，残腎の代償性肥大にどのような影響 を执よぼすかは, 腎の手術に関与する泌尿器科医にとつ て興味があると同時に, 臨床的にも重要な問題である. この問題に対しラットを用いた実験により，主として核 酸执よび蛋白量の変化を指標として検討を行つた.

腎摘除術後の観察日数は，MMC を投与した NM 群 で7日目に著明な DNA 含量の減少が認められたことも あり, 以後の推移をみるために14日目までとした。抗癌 阂の投与量は, 臨床的には MMC は 1 回量として数 $\mathrm{mg}$ のことが多く910), また 1 回量 $16 \mathrm{mg}^{11)}, 1 \mathrm{mg} / \mathrm{kg}^{12)}$ を投与する方法も報告されている，5-Fu では 1 回量 15 $\mathrm{mg} / \mathrm{kg}$ 前後を連日投与する方法 ${ }^{13)}$ が一般的である. 本実 験では MMC は0.292mg/kg, 5-Fu は $21 \mathrm{mg} / \mathrm{kg}$ と臨朱 投与量に近い量を用いたが，これはラットにおいて $1 / 10$ $\mathrm{LD}_{50}$ に相当する量である。なおこれらの抗癌剂投与に より臨床的には副作用として食思不振がしばしば経験さ れている. Williams ${ }^{14)}$ は腎摘除術後のラットに24時間 の絶食をさせると，残腎の mitotic activity を遅延させ ると報告しているため，抗癌㶡投与群のラットでは非投 与群に比し手術後の食慨摂取の開始時間に遅延がないか 否かを観察したが，ほとんど差異は認められなかつた。

本実験での腎重量左右比についてみると，抗癌剤非投 与群の N群では腎摘除術後 1 日目より経日的に増加し, 14 日目に夷験開始時に比し約 $40 \%$ の増加が認められた。
従来の報告によると, それらはある程度体重差を考慮 したものではあるが， ラットでは2 週目で約 $30 \%$ 増

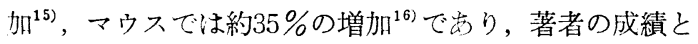
類似していた。一方，抗癌剂投与群の NM, NF 群では いずれも10日目までN群に類似した増加傾向が認められ たが，14日目にN群に比し低值であつた。 この低值を示 した一因として，実験開始時と終了時におけるラットの 体重の変化が考学られないかどらかにつき検討した．実 験開始時に対する終了時の体重の比をみると，14日目に N群では約1.2であるのに比し，NM，NF 群では約 1.05 で低值であり，また NM，NF 群では10日目よりも14日 目に低值であつた。腎重量の増加は体重の増加と関係す るといら報告 ${ }^{17)}{ }^{18)}$ もみられるため, 実験開始時に対する 終了時の体重の比の差が腎重量にある程度の影響をおよ ぼしたことも推定される. 腎重量の増加は個体の成長に も関係するため, 肥大腎重量の増加について, その点も 考慮する必要がある. Webster ${ }^{18)}$ はラットに拈ける腎重 量は体重の増加とともに緩徐な増加傾向を示すが，体重 に対する比でみると徐々に減少を示し，体重が $300 \mathrm{~g}$ 前 後ではほぼ横ばいか，わずかな減少であつたと報告して いる．以上のことより，本実験で使用した体重 $300 \mathrm{~g}$ 前 後のラットに秥いては, 体重に対する左腎重量の比が体 重差を考虑した腎重量の変化の指標となると考兄られ, 著者も同様の方法で検討を試みた。しかし個体差が大き いため各群での 有意の変化の検討は困難であつたが, $\mathrm{N}, \mathrm{NM}, \mathrm{NF}$ の3群ではいずれも偽手術をほどこした $\mathrm{S}, \mathrm{SM}, \mathrm{SF}$ 群に比し全体的に高值の傾向であつた。

皮質扎よび髄質重量の左右比は，N，NM，NF 群いず れに颃いても腎重量左右比の推移と類似して㧍り, 髄質 に対する皮質の重量比もほぼ一定であつた。重量につい ては代償性肥大腎は皮質, 髄質とも一様に增加寸ると解 釈できよう。

さて代償性腎肥大に拈いて, hypertrophy と hyperplasia のどちらがぞの程度関与しているかについては, 従 来より議論の多い点である. 細胞 1 個当りの DNA 含量 はほぼ一定とみなしうるため, hypertrophy があれば総 DNA 量は不変であるが, 総 RNA 量, 総蛋白量は当然 増加すると考えられる. そのため RNA/DNA 比および蛋 白/DNA 比も当然增加するが, DNA 濃度は相対的に減少 する.一方, hyperplasia では細胞が増加するため, 续 DNA 量, 総 RNA 量, 総蛋白量はいずれも増加する. ᄂ かし細胞の大きさは不変であるため, RNA/DNA 比は増 加しても, 蛋白/DNA 比と DNA 濃度の変化は比較的少 
ないと考觉られる。これらのことより抗癌剤非投与群で あるN群での hypertrophy の関与については倹討してみ ると, 皮質では総 RNA 量, 総蛋白量は14日目まで経日 的な增加傾向が認められたのに対し, 総 DNA 量の増加 は著明でなく，DNA 濃度も全体として14日目まで減少 傾向が認められた。また RNA 濃度は全体として軽度の 增加であり, 蛋白濃度はほとんど変化が認められなかつ た。 RNA/DNA 比打よび蛋白/DNA 比は1日目より增加 し，以後も全体として14日目まで増加傾向が認められ た. 髄質でもこれらの傾向に類似していた，以上より hypertrophy は皮質，䯣質いずれ打いても腎摘除術後 1日以内に始政り，14日目まで継続していると考觉られ た。

次に hyperplasia について検討してみると，皮質では 総 DNA 量が 3 日目に急激に增加し, DNA 濃度は回復傾 向が認められた。以後総 DNA 量は14日目までゆるやか な増加傾向が認められたが， DNA 濃度は腎重量の増加 が大きいため，全体として減少傾向が認められた．䯠質 でもほぼ同様の傾向であつたが，皮質に比し総 DNA 量 の増加は全体として軽微であり, DNA 濃度の減少は著 明であつた。以上ょり hyperplasia は皮質に怙いては1 日目と 3 日目の間に強く, その後も軽度ではあるが14日 目まで持続していると考党られた。䯣質でも同様の傾向 がみられたが皮質に比し軽度で出り，岡所の報告1)と注 ぼ一致していた. hyperplasia に関しては, mitotic activity は皮質，髄質とも2 日目まで活発であり，特に皮

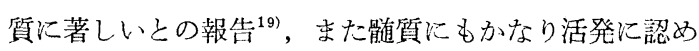
られたとする報告名もみられるが, mitotic activity は皮 質および䯣質の outer medulla に主として認められ， inner medulla では活発でないといわれている20121)。 た hyperplasia のおこる時期については, 皮質では 2 日 目から 3 日目の間に最高のピークがあり，またそれより 低いが 7 日目にもピークが認められたとの報告 ${ }^{22)}$, outer cortex では40時間目と8日目に, inner cortex 々 outer medulla では40時間目と 3 日目にピークが認められたと の報告 ${ }^{21)}$ な゙゙がある、本実験では最初のピークの時期は 諸家の報告とほぼ一致していたが，それ以後は14日目ま で明確なピークは認められず, hyperplasia は緩徐に持 続していると考えられた。

代償性肥大は皮質に打いては尿細管に主として扔こる との報告が多いために，尿細管を分離してその DNA 含 量, RNA 含量, 蛋白含量を測定した。しかし尿細管の 定量的回收が困難なために，RNA/DNA 比，蛋白/DNA
比のみで検討した。その結果， RNA/DNA 比抒よび㔻 白/DNA 比のいずれも皮質の变化に類似していた。比較 的早期の 5 日目頃までの推移をみると， RNA/DNA 比 の増加に対し, 蛋白/DNA 比の増加は明白でないことよ り，尿細管では hypertrophy より hyperplasia の関与が 主であると推定された。

以上の $\mathrm{N}$ 群の傾向 と比較しながら，抗癌剤投与群の $\mathrm{NM}, \mathrm{NF}$ 群について検討を加光る。 MMC を投与した NM 群では，皮質に拈いて全体としてN群に比し DNA 含量の低下は著明であるが， RNA 含量，蛋白含量以著 しい差は認められなかつた。1日目には総 DNA 量拉よ び DNA 濃度はともにほとんど変化が認められず，また RNA/DNA 比, 蛋白/DNA 比はN群比し低值で沙るた め, hypertrophy はN群でみられた湾どまだ活発でない と考学られた. 3 日目でも総 DNA 量の增加は淘々んど 認められず， DNA 濃度も減少しているため，N群でみ られた hyperplasia は抑制され, むしろ hypertrophy が 主であると考兄られた．5日目にもやはり総 DNA 量の 增加は汪とんど認められないが, 総 RNA 量, 総蛋白量 はいずれも增加しており, hypertrophy は継続している と考觉られた。しかし7日目には DNA 含量が著しく減 少し, そのため RNA/DNA 比抢よび蛋白/DNA 比は著 しい增加が認められた。これは hypertrophy によるため でも亦万らが， MMC の作用機序を考虙すると，核の DNA 崩壊による相対的上昇と考光られた，7日目以降 は総 RNA 量は14日目を除いてN群に比し著変は認めら れなかつたが，総蛋白量はやや低值であつた。そのため RNA/DNA 比に対し蛋白/DNA 比も低值であり，DNA 含 量の回復傾向と考党市わせると, hypertrophy はもちろ ん継続しているが, hyperplasia る急速に生じていると 考えられた。な拈䯣質拈よび尿細管でも皮質の傾向汇類 似していた。

MMC の作用機序についてみると, 芝 ${ }^{23)}$ は大腸菌 B 株 を，黑田ら ${ }^{24)}$ は HeLa 細胞を用いた実験で，MMCの 蛋白捛よび RNA 合成への影響は少ないが，DNA 合成を 強力に抑制したと報告している．細胞の形態学的変化に ついては, KB cell (human epidermoid carcinoma) で は早期に核の腫脹を来たし，最も変化の大きいものは核 小体であり，その核小体の segregation は 4 日目頃に 完成するとの報告 ${ }^{25)}$ ，細胞核を崩壊させて DNA を低分 子化させるとの報告 ${ }^{26)}$ な゙゙がるれる．分子レベルでは MMC は DNA 2 本鎖の間に cross linkage を来たし, DNA 複製時にプライマーとしての働きを阻害するとい 
われている27)。これらのことより MMC は主として DNA 合成阻害作用を有し，代償性腎肥大に括讨る細胞 の hypertrophy への影響は少ないが，3日目までにみら れる hyperplasia を抑制し，更に細胞の核の崩壊飞よ引 DNA 含量が 7 日目に著しい低下を示すもの之考えられ た。本実験に招いて MMC を為手術群に投与した SM 群では，偽手術のみの $\mathrm{S}$ 群と比較して，著明な变化は認 められないが，腎摘除術後に 投与した場合には，代償 性肥大の生じている残腎に与兄る影響は比較的大きい 之考学られる。このことは DNA 合成阻害作用を有する 抗癌剂は一般に分裂，增殖のさかんな細胞に対してより cytotoxic であることとよく一致する。また今回は此較 的低濃度の MMC を投与したために，hypertrophyへの 影響は少なく，更に7日目以後に hyperplasia 迈る回 復が招こつたものと考兄られた。本実験での結果をその ま亲人に步てはめることは問題で㘯るが，腎摘除術後に MMC を投与する場合， hyperplasia の強い時期に大量 を投与すると，回復不能な細胞障害が技こることが予想 されるので, hyperplasia の強い時期には避けた方が望 ましいと考兄られた。Janicki ら ${ }^{28)}$ は，DNA 合成阻害剂 である hydroxyurea は代償性肥大腎の DNA 合成汇抑制 作用を示したが，RNA 量，蛋白量への影響は認められ なからたと本実験に類似した報告をしている。

MMC による腎障害については臨床的にも教多くの報 告があり，成因海関する研究も多いが，詳細については いまだ意見の一致がみら礼ていない，糸球体の核の変化 が婜障害の原因であると強調する報告 ${ }^{12)}$ みられるが， 本実験の結果より，注と儿どすべての腎細胞において障 害がおこると考光られた。な扮藤田ら ${ }^{299}$ は，MMC の静 注後には，血中濃度はすみやかに上昇した後に対数的に 減少していくのに対し，尿中濃度は一杵高値を示し，注 射後30１20分で最高值に達し， 尿中排泄量は投与後 4 時間までは注入薬剤量の $10 \%$ 以内で多くなかつたが，モ ルモットでは組織内濃度は腎で最も高かつたと報告して 牤り，MMC の腎への影響については注意を払う必要が ある・

次汇 5-Fu 投与群の NF 群についてみると，皮筫，䯣 質ともに1日目には総 DNA 量打よび DNA 濃度は注と んど変化が認められないが， RNA 含量および蛋白含量 はN群に比し，特に皮質に和いて著しい減少が認められ た。笛のため RNA/DNA 比と蛋白/DNA 比も特に皮質に おいて著しい減少が恋められた。このことより $\mathrm{N}$ 群でみ られた1 日目の hypertrophyは，特に皮質に执いて強く
抑制されていると考觉られた。3日目でも総 DNA 量の 増加はほとんど認められず，DNA 濃度も減少していた。 一方，RNA 含量および蛋白含量はN群と比較して著し

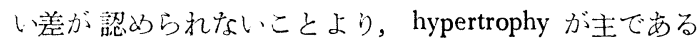
と考克られた。 5 日目には DNA 濃度に軽度の回復傾向 が認められたが，総 DNA 量の增加はわずかであるため に, hyperplasia の関与は乏しい之考光られた。 5 日目 以降も総 RNA 量抢よび総蛋白量は増加傾向が認められ たが，14日目にはN群に比し低值であつた．RNA/DNA 比拈よび蛋白/DNA 比も14日目に特に皮質氾おいて増加

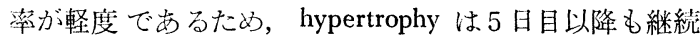
しているが，14日目には皮質に招いては著明でないと推 定された。な打総 DNA 量は7 日目以降ゆるやかな增加 傾向が認められ，DNA 濃度も全体として回復傾向が認 められたことより， hyperplasia も生じていると考えら れた。

5-Fu は pyrimidine 代謝拮抗性の抗癌剂であり，关れ は deoxyuridine monophosphate より thymidine monophosphate への変換汇関与する thymidilate synthetaseを ブロックナるために，DNA 合成を阻害するといわれて いる。また fluorouridine monophosphate が uridine monophosphate と競合して F-RNA となるために, RNA 合

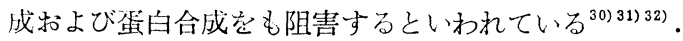
これらのことより 5-Fu は DNA，RNA 抢よび蛋白合成 のいずれをる阻害し，代償性腎肥大に対しては1日目ま での hypertrophy の強い抑制と 3 日目までの hyperplasia の抑制が認められたが，以後の影響は少ないと考党られ た. 藤本ら ${ }^{33}$ は 5-Fu は肝での異化が非常に早く，投与 30 分後には投与量の $85 \%$ が抗癌作用を失つていたと報告 しておりまた5-Fuは time dependent な薬剤であるた め, 臨床的には連日投与が一般的である. 本実験では 1 回投与したのみであるが, hypertrophy 拈よび hyperplasia に対する影響が認められた。 MMC の場合と異なり， 5-Fu は DNA の崩壊を伴わないが，腎摘除術後に投 与する場合には，残腎への影響を少なくするために， hypertrophy および hyperplasia の活発な時期を避けた方 が望ましいと考兄られる．動物実験の成績がとのまま臨 床にあてはまるかどうかの問題があり，人に抢いては代 償性腎肥大の詳しい経過は不明であり，また墨性腫愓と いう重大な疾患に対する問題などを考虑すると，投与時 期についてはさらに検討すべき面が残されていると考兄 られる。

MMC あるいは 5-Fu 以外の抗癌剤, たとえば mithr- 
amycin, actinomycin D, cycloheximide の代償性腎肥大 に打よぼす影響を検討した報告 ${ }^{34) 35}$ とよると，核酸量， 蛋白量，腎重量などになんらかの影響を拉よ汸している 場合が多い。このことは必ずしも腎機能の低下に值接絬 びっくわけではないが，腎機能の低下を認めたとの報 告 ${ }^{35)}$ るある. 臨床的には抗癌剤之術後感染予防のための 抗生剤の併用などの問題が㘯り, 更に複雑な生体内機序 も予想されるので，腎摘除術後早期の抗癌剤投与に際し ては，投与量，投与時期などに関して十分な配虑が必要 であると考えられる。

\section{結 語}

ウィスター系雄性ラットを用いて，代償性腎肥大に およぽす MMC 㐫るいは 5-Fuの影響を，督摘除術後 1 ～14日に核酸量および蛋白量の変化を指標として検討 し, 次の結論を得た。

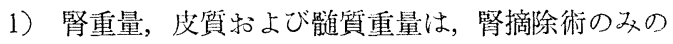
群では14日目まで経日的な増加傾向が認められた。抗癌 剂投与群でも10日目まで注涪同様の傾向が認められた が，14日目には腎摘除術のみの群に比し低值であつた。

2）腎摘除術の及の群では，皮質，䯣質ともに残腎の hypertrophy は1 日以内に始まり，14日目まで汇継続し ていた。一方，hyperplasia は皮質では1日目と 3 日目 の間に強く, その後も軽度ではあるが14日目まで持続し て招り，髄質でも同様の傾向であつたが，皮質に比し軽 度であつた。

3） MMC 投与群では，代償性肥大謷の皮質扣よび 葡質に扣いて， hypertrophy への影響は少なかつたが， hyperplasia に対する抑制は強く，7日目には細胞の核 の崩壊によると考兄られる DNA 含量の著しい低下が認 められた。 その後は急速な回復傾向が認められた。

4）5-Fu 投与群では，皮質扔よび骵質において，

1 日目末での hypertrophy の強い抑制と 3 日目までの hyperplasia の軽度の抑制が譛められたが，元の後の影 響は少なかつた。

5）尿細管では腎摘除術のみの群，MMC 投与群之も に，皮質の傾向に類似していた。

6）腎摘除術後早期の抗癌剂使用に際しては, 残筱機 能に対する十分な配慮が必要で西ると考光られた。

稿を終わるにあたり，終始御想篤な御指導，御校閲を 賜方った恩師黑田恭一教授汇梁甚なる感謝の意を垡しま

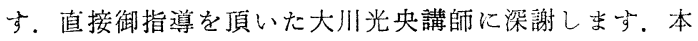
研究に御協力頂いた腎研究班の諸兄, 教室員各位ならび に男中耕一文部技官の御厚意に感謝します。告た, 生化
学的操作少よび化学的測定汇ついて御指尊, 御的言を頂 いた本学生化学教室久野滋教授に謝意を表します。

本論支の要旨は第23回日本腎臟学会総会 (東京, 1980)

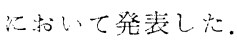

\section{文献}

1) 岡所 明：実験的代償性 肥大腎 の生化学的研 究. 日泌尿会誌, 71，1398-1410，1980。

2) Helwig, J.J., Zachary, D. and Bollack, C. with the technical assistance of Krill, J.M.: Isolation of glomeruli and tubular fragments from rabbit kidney. Urol. Res., 2, 55-59, 1974.

3) Ahn, H.S. and Strausser, H.R.: Isolation of viable rat kidney tubules. Life Sci., 10, 223232, 1971.

4) Burton, K.: A study of the conditions and mechanism of the diphenilamine reaction for the colorimetric estimation of deoxyribonucleic acid. Biochem. J., 62, 315-323, 1956.

5) Schneider, W.C.: Determination of nucleic acids in tissues by pentose analysis. in Methods in enzymology, Colowick, S.P. and Kaplan, N.O., Vol. 1II, p. 680, Academic Press Inc., New York, 1957.

6) Lowry, O.H., Rosebrough, N.J., Farr, A.L. and Randall, R.J.: Protein measurement with the Folin phenol reagent. J. Biol. Chem., 193, 265-275, 1951.

7) Goss, R.J. and Rankin, M.: Physiological factors affecting compensatory renal hyperplasia in the rat. J. Exp. Zool., 145, 209-216, 1960.

8) Sulkin, N.M.: Cytologic studies of the remaining kidney following unilateral nephrectomy in the rat. Anat. Rec., 105, 95-107, 1949.

9) 黒川利雄, 海藤 勇 : 癌化学療法の現況之将 来. 治療, 42, 194-210, 1960 .

10）島田信勝，石井良治：制癌剤と白血球減少. Chemotherapy, 10, 1-14, 1962.

11）松永藤雄, 山口保, 梶原実, 德阔潤三, 石 由実，黑滝良宏，鈴木竹一，田村克美，下山 孝, 鈴木啓充, 花田雅寧, 三川 清: 内科領域

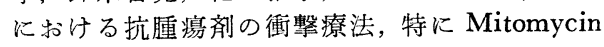
$\mathrm{C}$ による大量間歇投与法について。癌の臨床, 9, 640-648, 1963.

12) Liu, K., Mittelman, A., Sproul, E.E. and Elias, E.G.: Renal toxicity in man treated with mitomycin C. Cancer, 28, 1314-1320, 1971.

13) 斎藤達婎, 横山正和: 各種抗癌剤の作用機序上 抗癌スペクトル。 日本臨床, 33，1768-1793, 1975.

14) Williams, G.E.G.: Studies on the control of compensatory hyperplasia of the kidney in the 
rat. Lab. Invest., 11, 1295-1302, 1962.

15) Tomashefsky, P. and Tannenbaum, M.: Macromolecular metabolism in renal compensatory hypertrophy. I. Protein synthesis. Lab. Invest., 21, 358-364, 1960.

16）川原信義：代償性腎肥大に関与る実験的研究. 信州医誌，23，277-292，1975.

17) MacKay, L.L. and MacKay, E.M.: Factors which determine renal weight. II. Age. Am. J. Physiol., 83, 191-195, 1927.

18) Webster, S.H., Liljegren, E.J. and Zimmer, D.J.: Organ: body weight ratios for liver, kidneys and spleen of laboratory animals. I. Arabino rat. Am. J. Anat., 81, 477-513, 1947.

19) Rollason, H.D.: Compensatory hypertrophy of the kidney of the young rat with special emphasis on the role of cellular hyperplasia. Anat. Rec., 104, 263-285, 1949.

20）梅田 隆, 小磯謙吉：代償性腎肥大. 腎と透 析, 4, 13-19, 1978.

21) Williams, G.E.G.: Some aspects of compensatory hyperplasia of the kidney. Brit. J. Exp. Path., 41, 386-396, 1961.

22) Bury, H.P.R., Crane, W.A.J., Path, M.C. and Dutta, L.P.: Cell proliferaticn in compensatory renal growth. Brit. J. Urol., 37, 201--210, 1965.

23）芝茂：マイトマイシンの作用機序. 最新医 学, 14, 1-7, 1959.

24) Kuroda, Y. and Furuyama, J.: Physiological and biochemical studies of effects of mitomycin $\mathrm{C}$ on strain HeLa cells in cell culture. Cancer Res., 23, 682-687, 1963.

25) Lapis, K. and Bernhard, W.: The effect of mitomycin $\mathrm{C}$ on the nucleolar fine structure of $\mathrm{KB}$ cells in cell culture. Cancer Res., 25, $628-645,1965$.

26) Shatkin, A.J., Reich, E., Franklin, R.M. and Tatum, E.L.: Effect of mitomycin C on mam- malian cells in culture. Biochim. Biophys. Acta, 55, 277-289, 1962.

27) Iyer, V.N. and Szybalski, W.: A molecular mechanism oî mitomycin action: Linking of complementary DNA strands. Proc. N. Acad. Sci., 50, 355-362, 1963.

28) Janicki, R. and Lingis, J.: Unabated renal hypertrophy in uninephrectomized rats treated with hydroxyurea. Am. J. Physiol., 219, $1188-1191,1970$.

29）藤田 浩, 木村跴代二：Mitomycin C の血中 組䢂内濃度。癌の臨床, 別冊癌, 化学療法, 80 - 85,1966 , 医歯薬出版。

30) Danneberg, P.B., Montag, B.J. and Heidelberger, C.: Studies on fluorinated pyrimidines. IV. Effects on nucleic acid metabolism in vivo. Cancer Res., 18, 329-334, 1958.

31) Bosch, L., Harbers, E. and Heidelberger, C.: Studies on fluorinated pyrimidines. V. Effects on nucleic acid metabolism in vitro. Cancer Res., 18, 335-343, 1958.

32) Heidelberger, C. and Ansfield, F.J.: Experimental and clinical use of fluorinated pyrimidines in cancer chemotherapy. Cancer Res., 23, 1226-1243, 1963.

33）藤本 茂, 赤尾建夫, 腰塚 格, 伊藤支二, 小 谷野勝治, 栭川征夫, 高橋誠, 南 智仁, 石 神博昭, 宮崎 勝, 伊藤健次郎 : 5-fluorouacil の経口投与に関する検討。癌の臨床，22，28一 31, 1976.

34) Resnick, M.I., Albert, D.J. and Persky, L.: Inhibition of compensatory renal hypertrophy with mithramycin. J. Urol., 108, 194-196, 1972.

35) Northrup, T.E. and Malvin, R.L.: Cellular hypertrophy and renal function during compensatory renal growth. Am. J. Physiol., 231, $1191-1195,1976$.

（1981年 3 月 14 日受付，特別掲載） 